\title{
Building bridges between organisational change and quality management in New Zealand
}

\author{
Siham El-Kafafi ${ }^{1 *}$ \\ Manukau Business School, Institute of Technology, Auckland, New Zealand
}

(Received June 29 2006, Accepted July 22 2006)

\begin{abstract}
This paper reports on a case study examining the drinking water management system of one Territorial Local Authority (TLA) in the Waikato Region of New Zealand. This specific TLA was chosen because it took the leadership role as the first TLA in the region to strive for business excellence by providing the best water service to the community. That TLA chose the path of organisational change through adopting a Total Quality Management (TQM) Model i.e. ISO 9000 Certification as a means of building bridges between the two concepts.

This case study shows how organisational excellence was integrated in the TLA's strategy through their understanding of the core business process (i.e. service delivery to the community) and through involvement of the community. The research preceded by comparing theory and practice by analysis of three sets of data collected by two different techniques. The researcher conducted face to face interviews with the management team at the TLA. In addition, the researcher utilised participant observation techniques to document the actual practices of the regular working day of plant technicians at the water treatment plant of that respective TLA.

The paper emphasises the importance of breadth and depth of organisational change in the TLA in view. It reports on findings from both the qualitative themes and quantitative variables and finally gives recommendations for future actions.
\end{abstract}

Keywords: territorial local authorities managerial practices, organisational change, service quality, ISO 9000 certification, drinking water quality, Waikato Region

\section{Introduction}

This paper is part of a bigger study investigating the adoption and adaptation of Total Quality Management (TQM) and its models (ISO 9000, ISO 14000 and Quality Awards) in the Water Utilities within a Territorial Local Authorities (TLAs) in the Waikato Region of New Zealand and its impact on the quality of drinking water quality provided to the community. This paper reports on one case study out the nine case studies of the region under investigation. The research starts by giving the definition of quality of service which plays an important role in providing a quality product i.e. drinking water quality, then a brief background of the Waikato Region in which the TLA under investigation is located. The paper endeavours to explain the meaning of "service quality" and its relation to this study. Thirdly the paper explains the methodology chosen for this study in which three sets of data collection [(a) face to face interviews with managers of the TLA under investigation, (b) participant observations of the water treatment plant of the TLA, and (c) official documents of other studies] were analysed. Finally the paper will present research findings and give recommendations for future actions.

\footnotetext{
*E-mail address: siham.elkafafi@ manukau.ac.nz
} 


\section{What is quality of service}

Charles S. Tapiero in his book "The Management of Quality and its Control" (1996) ${ }^{[20]}$ stated that "quality of service' differs from quality of manufacturing which depends on the quality of product. Quality of service depends on both the 'server' and 'serviced'. Poor service is usually defined by the dissatisfaction of the serviced. Services are mostly intangible, often subjective, and are therefore difficult to define. Moreover a service is not storable, unlike products that can be sampled and tested for quality. Accordingly, there are several approaches to the definition of quality of service.

The following Fig. 1 sums up The American Society for Logistics (ASLOG ${ }^{[6]}$ ) approach in defining quality of service in terms of communication, time, organisation, flexibility, reliability and post sales service ${ }^{[20]}$.

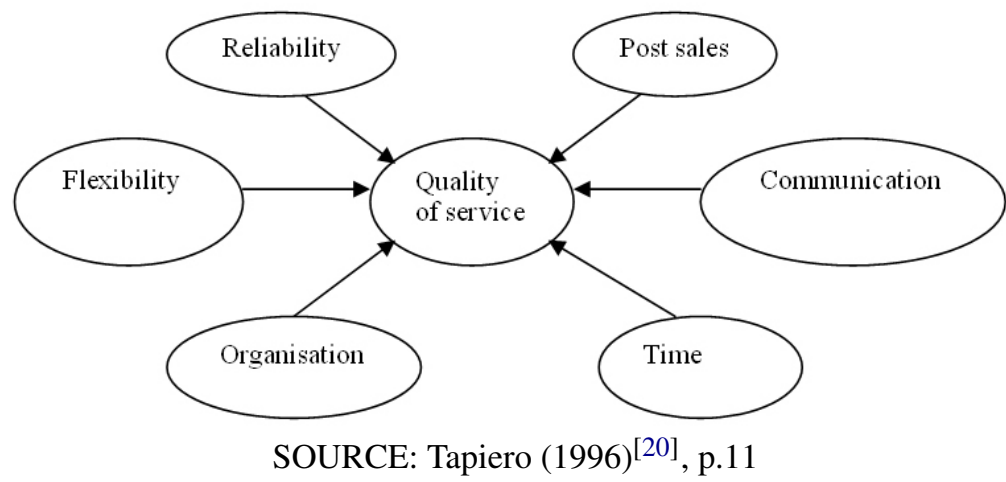

Fig. 1. ASLOG suggested dimensions of service quality

Communication could be measured by the opportunity for errors, document errors, billing, client follow through and information exchange (i.e. in our case study it would be related to the information published for community use in relation to drinking water quality). Time relates to delays of various sorts e.g. supply responses to community queries, conformance to the New Zealand Drinking Water Standards and distribution of water to community. Organisation includes the range of services delivered and agreed upon, security in stocking (i.e. water pipes). It also includes organisational forms such subcontracting (i.e. purchase of chemicals and maintenance of equipments). Flexibility is in relation to the potential of meeting demands under various circumstances (i.e. increase in water demand during the summer season), and to adapt to a broad range of operational and service conditions. Reliability refers to the consistency of the service supplied (i.e. keeping the water grading at ' $A$ ' ' $a$ ' level in compliance with the New Zealand Drinking Water Standards) and continuity of water supply to the community to meet their demand in a timely manner. Finally, post sales service applies to maintainability, reliability, service proximity and availability.

Another approach to define quality of service was suggested by [13] by stating Maslow's hierarchy or pyramid of needs in which he explained that higher levels of quality (i.e. emotional needs) can be achieved only if the lower levels are satisfied first. The following Fig. 2 illustrates the levels of service required for quality awareness.

The following is [13] interpretation of the levels of service quality according to Maslow's hierarchy of needs:

1. Level One: Congruence of employees' and customers' behaviours (i.e. interlocking behaviours). In relation to our case study it would be the degree of politeness of the TLA's employees in answering to the public's complaints in relation to the provision of drinking water.

2. Level Two: Perceived degree of satisfaction combined with technical services which can be observed and measured objectively. In our case it would be the pressure and continuity of water to households in the community.

3. Level Three: Degree of emotional satisfaction. For example how the community feels about inclusion by the TLA asking their opinions about how satisfactory is their service to them. 


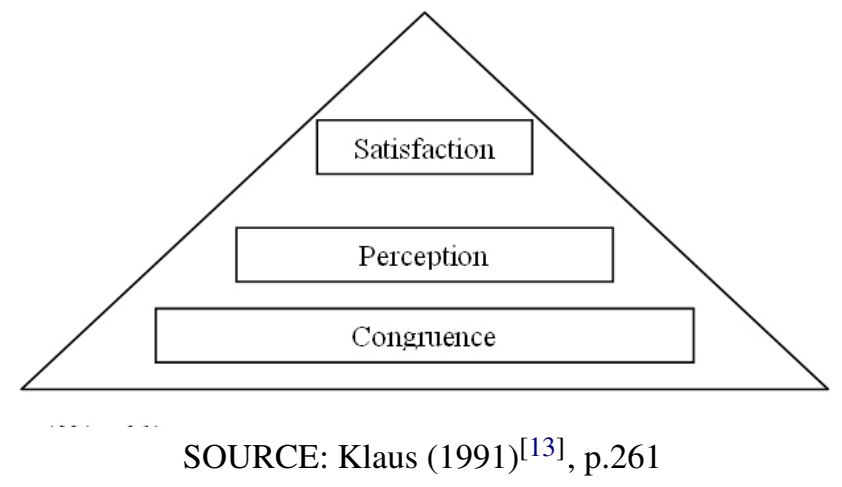

Fig. 2. Levels of service quality awareness

It should be noticed that both definitions of quality of service is revolving around customer satisfaction which is the essence of quality.

\section{The Waikato Region}

Waikato Region covers 25,000 square kilometres in the central North Island of New Zealand. It contains a rich diversity of natural resources including snow-capped mountains, extensive rive and lake systems, forests, geothermal fields and productive farmland. A human population of 357,726 (Statistics New Zealand, 2005 Census ${ }^{[4]}$ ) live in the Waikato Region mostly urban areas. Within the Waikato region are the rohe, or tribal areas, of a number of iwi ${ }^{2}$. Waikato Iwi include Tainui, Tuwharetoa and Ngati Tahu ${ }^{[1-3]}$.

The Waikato Region is well endowed with water resources as shown on Tab. 1.

The Waikato Region is an area of New Zealand, which is highly dependent on surface water from rivers and lakes to supply its drinking water needs. Accordingly the Territorial Local Authorities (TLAs) with the assistance of Environment Waikato gives great importance to the following issues ${ }^{[1,2]}$ :

- maintaining and improving water quality,

- maintaining and enhancing flow regimes,

- efficient use of water, and

- enhancing public access.

Table 1. Key Waikato water resources

\begin{tabular}{ll}
\hline Rivers and Lakes & Description \\
\hline Waipa River & The longest river in New Zealand and is considered \\
& Contributes to extensive flood plains in the north \\
Piako River & Extensive flood plains in then north \\
Waihou River & Extensive flood plains in the north \\
Lake Taupo & Exceptional water quality \\
\hline \multicolumn{2}{l}{ SOURCE: Waikato Regional Council, September, 1998. }
\end{tabular}

\section{Research methodology}

This research used two types of triangulation i.e. data triangulation (face-to-face interviews, observations, and document review) and methodological triangulation (qualitative and quantitative data collection and analysis).

\footnotetext{
${ }^{2}$ Maori in New Zealand identify with and are identified through three levels of organization - Iwi - tribal level, hapu - clan and whanau - extended family.
} 
The rationale behind the choice of using triangulation is that no single method adequately solves the problem of rival causal factors ${ }^{[9]}$. Hence, by the use of multiple methods the researcher aspires to reveal the different aspects of empirical reality and at the same time help validate the research findings. Moreover, triangulation is the best means of answering the following four sub-questions of the research who have got both qualitative and quantitative aspects. Furthermore, Fig. 3 illustrates the TQM Model as a means of organisational change in this case study.

1. What perceptions do water utilities managers have about quality management in general and TQM in particular?

2. To what extent are TQM practices actually applied in the water utilities?

3. Is there a relationship between the use of specific TQM procedures/models and water quality?

4. What other quality factors do managers in water utilities identify as crucial for improvement of water quality?

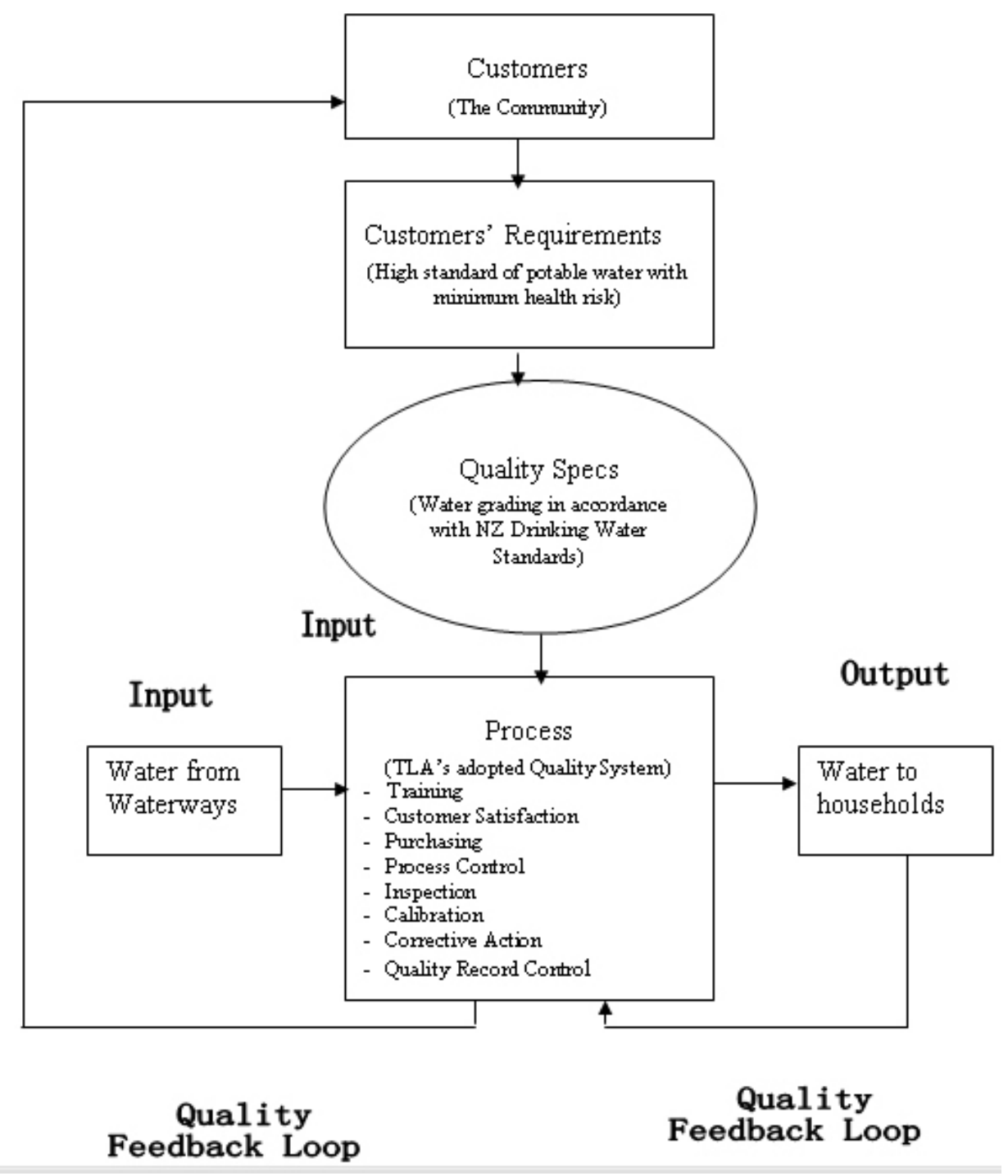

SOURCE: Author's figure

Fig. 3. TQM Model as a means of organization change in the case study 


\section{Sample selection of case study}

This TLA serves a population of 120,000 . It was chosen because it took the leadership role as the first TLA in the region to strive for business excellence by providing the best water service to the community. The non-probability sampling method is the method chosen as a means of discovering what occurs, the implications of what occurs and the relationships linking occurrences. Non-probabilistic sampling strategy has also been called "purposive" sampling by [7] and "purposeful" by [17].

Snowball, chain, or network sampling [17] is the form of purposeful sample used in this research. The researcher identified the participants through contacting people in the TLA and asking about the most suitable and knowledgeable persons in the area to be interviewed. Accordingly, the researcher identified the most knowledgeable participants who could best inform the research. Due to their knowledge from their daily contact in the field, Managers of Water, Drainage and Refuse and the Water Treatment Managers of the TLA were selected. The result was five Managers from the TLA were interviewed.

\section{Data collection and analysis}

\subsection{Face to face interviews}

The researcher used the interviewing technique as the main data collection instrument because it yields rich insights into people's experiences, opinions, aspirations, attitudes and feelings ([5], [14], [15]). In accordance with the research requirements, the researcher formed the structured interviews to serve both quantitative and qualitative dimensions that vary from the formal standardized example of surveys ([15]). The interviews were conducted during the months of September, October and November of the year 2000. The following Fig. 4 shows to what extent TQM and its Models are actually applied in the TLA under investigation. Those are the results of the qualitative analysis of the face-to-face interviews in accordance with the eight criterions shown in Fig. 3.

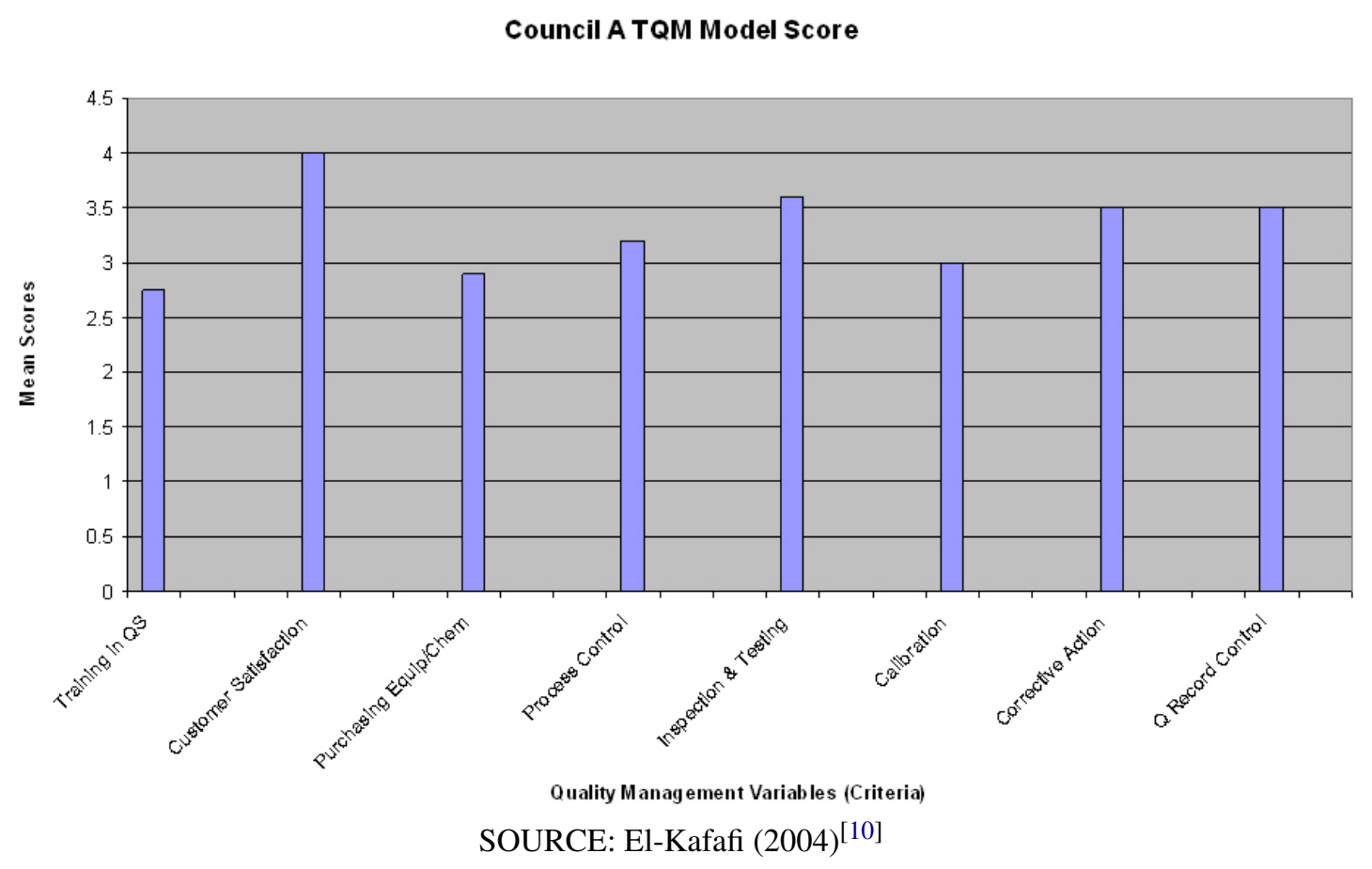

Fig. 4. TLA 'A': Average mean of all quality criteria

The data was analysed where 0 was the lowest score and 4 was the highest score. The above Fig. 4 shows to what extent TQM and its Models are actually applied in the TLA. It is worth mentioning here that although 
the analysis for this model was formulated by the researcher, the outcome is according to how the utility management scored itself in relation to the TQM Model. According to this analysis, "customer satisfaction" criteria scored the highest (i.e. 4) while "training in quality systems" scored the lowest (i.e.2.75).

The following Tab. 2 and Tab. 3 sums up the perspectives on water quality after analysing TLA 'A' managers interview questions.

Table 2. Major categories perspectives on water quality: Analysis of TLA 'A' managers interview questions

\begin{tabular}{|c|c|c|c|}
\hline Category & Sub-category & Definition & Sample Quote \\
\hline $\begin{array}{l}\text { Managerial Perception } \\
\text { of Quality } \\
\text { Management }\end{array}$ & $\begin{array}{l}\text { Who is responsible } \\
\text { for water quality in } \\
\text { the water utilities }\end{array}$ & $\begin{array}{l}\text { How does management } \\
\text { perceive and } \\
\text { define quality }\end{array}$ & $\begin{array}{l}\text { *Meeting customers needs } \\
* \text { Consistency of product and } \\
\text { getting things right the first time } \\
* \text { Continual improvement } \\
* \text { High Standard of Service } \\
* \text { Reliability of supply }\end{array}$ \\
\hline $\begin{array}{l}\text { Managerial Perception } \\
\text { of Quality } \\
\text { Management }\end{array}$ & $\begin{array}{l}\text { CEO perception } \\
\text { of TQM }\end{array}$ & $\begin{array}{l}\text { what aspects } \\
\text { of the TQM } \\
\text { experts are they } \\
\text { applying e.g. leadership } \\
\text { employee participation }\end{array}$ & $\begin{array}{l}* \text { Group discussions i.e. team } \\
\text { based problem solving techniques } \\
* 5 \text { Petal Process and training } \\
\text { of line management } \\
\text { *Fish bone charts and usage of } \\
\text { Opportunity for Improvement } \\
\text { (OFI) forms in weekly meetings } \\
\text { *Conducting } 3 \text { monthly } \\
\text { surveys of customers }\end{array}$ \\
\hline $\begin{array}{l}\text { TQM Models applied } \\
\text { in water utilities }\end{array}$ & $\begin{array}{l}\text { What quality } \\
\text { management system } \\
\text { is applied in } \\
\text { water utilities }\end{array}$ & $\begin{array}{l}\text { i.e. quality models } \\
\text { like ISO } 9000 \text { Series } \\
\text { or ISO } 14000 \text { Series }\end{array}$ & $\begin{array}{l}\text { *No ISO } 14000 \text { certification; } \\
\text { nevertheless, the TLA's } \\
\text { environmental mission } \\
\text { statement is guided by the principles } \\
\text { of Agenda } 21 \text { and recognises its direct } \\
\text { responsibilities under } \\
\text { the Resource Management } \\
\text { Act (1991) to sustainably manage } \\
\text { the TLA's environment } \\
\text { for the existing generation } \\
\text { and the future generations. } \\
\text { *Water Treatment Plant has been } \\
\text { ISO9002 certified for } 8 \text { years. } \\
\text { *The lab at the Water Treatment } \\
\text { Plant is IANZ certified i.e. ISO } 17025 . \\
\text { *The Works and Services Group i.e. } \\
\text { the department responsible } \\
\text { for the provision } \\
\text { and supply of drinking water quality } \\
\text { to the consumers obtained the } \\
\text { ISO } 9002 \text { on March } 2000 .\end{array}$ \\
\hline $\begin{array}{l}\text { TQM Models benefits } \\
\text { on Water Quality }\end{array}$ & $\begin{array}{l}\text { The benefits of } \\
\text { implementing quality } \\
\text { management models }\end{array}$ & $\begin{array}{l}\text { Has there been } \\
\text { improvement since } \\
\text { implementing the } \\
\text { models and are } \\
\text { they maintaining it }\end{array}$ & $\begin{array}{l}\text { *Improvement in cost, } \\
\text { more consistency of service provided. } \\
\text { *Compliance with most } \\
\text { of the elements } \\
\text { of ISO } 9000 \text { standards. } \\
\text { *The TLA is looking in the } \\
\text { future to apply for the Business } \\
\text { Excellence Award as a corporate body. }\end{array}$ \\
\hline
\end{tabular}


Table 3. Minor categories perspectives on water quality: Analysis of TLA 'A' managers interview questions

\begin{tabular}{|c|c|c|}
\hline Category & Definition & Sample Quote \\
\hline $\begin{array}{l}\text { Implementing TQM } \\
\text { Models i.e. ISO 9000/14000 } \\
\text { Certifications }\end{array}$ & $\begin{array}{l}\text { Reasons and motivation } \\
\text { behind obtaining the } \\
\text { certification }\end{array}$ & $\begin{array}{l}\text { *Customer satisfaction and } \\
\text { implementing a management } \\
\text { tool towards the improvement } \\
\text { of water quality. } \\
\text { *To comply with the } \\
\text { requirements of the NZ } \\
\text { Drinking Water Standards } \\
\text { to achieve an 'A' } \\
\text { grading of drinking water quality. } \\
\text { *A requirement by top management. } \\
\text { *Achieve a certain benchmark and } \\
\text { pick a national standard to prove } \\
\text { to customers that the TLA's work } \\
\text { is up to a recognised } \\
\text { international standard. }\end{array}$ \\
\hline $\begin{array}{l}\text { Implementation challenges } \\
\text { of TQM Models i.e. } \\
\text { ISO 9000/14000 Certifications }\end{array}$ & $\begin{array}{l}\text { How far did } \\
\text { the water utilities } \\
\text { implement the model } \\
\text { as a means of } \\
\text { quality assurance and } \\
\text { what are the challenges } \\
\text { confronting them } \\
\text { in maintaining } \\
\text { the TAM model. }\end{array}$ & $\begin{array}{l}\text { *Points of strength } \\
\text { in the implementation: } \\
\text { senior management } \\
\text { responsibility, documentation and } \\
\text { data control of } \\
\text { quality system, } \\
\text { contract reviews, } \\
\text { purchasing procedures, } \\
\text { identification and } \\
\text { traceability process control, } \\
\text { inspection and test status, } \\
\text { corrective and preventive actions, } \\
\text { handling, storage, packaging, } \\
\text { preservation and delivery, } \\
\text { internal quality audits, } \\
\text { training and maintenance. } \\
\text { Points of weakness } \\
\text { that needs more improvement: } \\
\text { more frequent training } \\
\text { to staff related } \\
\text { to quality control. }\end{array}$ \\
\hline $\begin{array}{l}\text { Have the water } \\
\text { utilities received any } \\
\text { awards (another TQM model) }\end{array}$ & $\begin{array}{l}\text { Is there any relevance } \\
\text { between awards and } \\
\text { drinking water quality }\end{array}$ & $\begin{array}{l}\text { There is no clear } \\
\text { cut answer for } \\
\text { this question since } \\
\text { the unit responsible } \\
\text { for the provision } \\
\text { of water hasn't } \\
\text { applied yet for the } \\
\text { award. Nevertheless, } \\
\text { the TLA is looking } \\
\text { into the principles } \\
\text { of the award as a } \\
\text { step for applying } \\
\text { for the award } \\
\text { in the future. }\end{array}$ \\
\hline
\end{tabular}




\subsection{Participant observation}

Observations are another source of data collection utilized in this study. Collecting data through observation is referred to as "participant observation" $[8,12,16]$. The researcher used the observation method deliberately by visiting the water treatment plant of the TLA under investigation as a means of check and control on the validity and reliability as part of the data triangulation process. The observations were conducted between the months of July 2001 until January 2002. Further visits to the TLA were conducted on January/February 2003 to check progress and update data. The observations were related to the face to face interview themes both quantitatively and qualitatively. The following section sums up the related themes.

\subsubsection{Relating the observations with the qualitative analysis}

The researcher related the observations conducted in the water treatment plant to the themes found while analysing the qualitative part of the fact to face interviews i.e. managerial perceptions of TQM Models. The following themes came up:

1. Quality Definition: in theory and practice both managers and technicians believe in quality of service and compliance to the New Zealand Drinking Water Standards to minimise health risk They also believe in customer satisfaction.

2. Innovativeness: the TLA is adopting a continual change perception to improve in the process of water treatment to reach the best results.

3. Teamwork: good communication system between the employees which is a door to a good working environment with all information shared and jobs done in a timely fashion.

4. Responding to Opportunity: the TLA took the opportunity to be the first in the Region to be ISO 9000 Certified to be able to compete in the international market and keep a good reputation that made it earn its customer's trust.

5. Common Vision: the TLA's vision statement is in line with its employees and customers vision.

6. Expertise: the ability of the TLA employees to react professionally in crisis. Model.

7. Leadership: the TLA taking the leading role to adopt organisational change by adapting the TQM

\subsubsection{Relating the observations with the quantitative analysis}

The following are the findings from the observations as related to the eight criteria presented in Fig. 3 .

1. Training: Water treatment technicians get trained by going to workshops and on job training.

2. Customer Satisfaction: it is the main focus of the whole organization who is always conducting surveys for the sake of feedback to improve on their shortcomings.

3. Purchasing Equipment/Chemicals: Quality plays a great role but sometimes price can affect managerial decisions.

4. Process Control: the process is always monitored during working hours and the technicians are on pager systems in case any problem arises after hours.

5. Inspection \& Testing: the TLA has got both an internal and external auditing system to support quality assurance of the system.

6. Calibration: equipment is being calibrated regularly and dates documented to keep track of next time its required to be done.

7. Corrective/preventive action: the TLA employees endeavour to use quality improvement tools e.g. fish bone and statistical analysis for finding out the source of the problem and taking the right measures to prevent it in future.

8. Control of Quality Records: every step of the process is documented and the important steps are then compiled to be fed in a computer system on a weekly basis to enable easy access and retrieval whenever information is required. 


\subsection{Document review}

Document review is the third source of data collection utilised in this study. As [16] stated that the term documents is referred to written materials in case study research. The researcher has followed the advice of [18] and [19] in the selection of documents for analysis (e.g. TLA reports, research studies of public opinion surveys and Ministry of Health Community Register). In accordance with the theme of this paper i.e. organisational change, this section presents how the organization is keen on continual improvement through the use of "Quality Feedback Loop" by conducting regular surveys to obtain feedback from its customers to help find out the points that require strengthening. The following Fig. 5, 6, 7, and 8 sums up the customers' surveys conducted since 1990 until 2001. The four figures shows that there is a slight trend of increased satisfaction over the twelve years. These surveys also capture respondent comments. The following are illustrative descriptions and comments from the community that lie behind the poor rating for the clarity of water as shown in Fig. 5 Those comments are excerpts from the 2002 Customer Surveys conducted by a market research company and commissioned by TLA 'A':

"I can see organic pieces of stuff when I hold it up to a light"

"sometimes its got things floating in it"

"it's got too much chlorine in it"

"we had black gunk in the water recently when the pipes were being flushed"
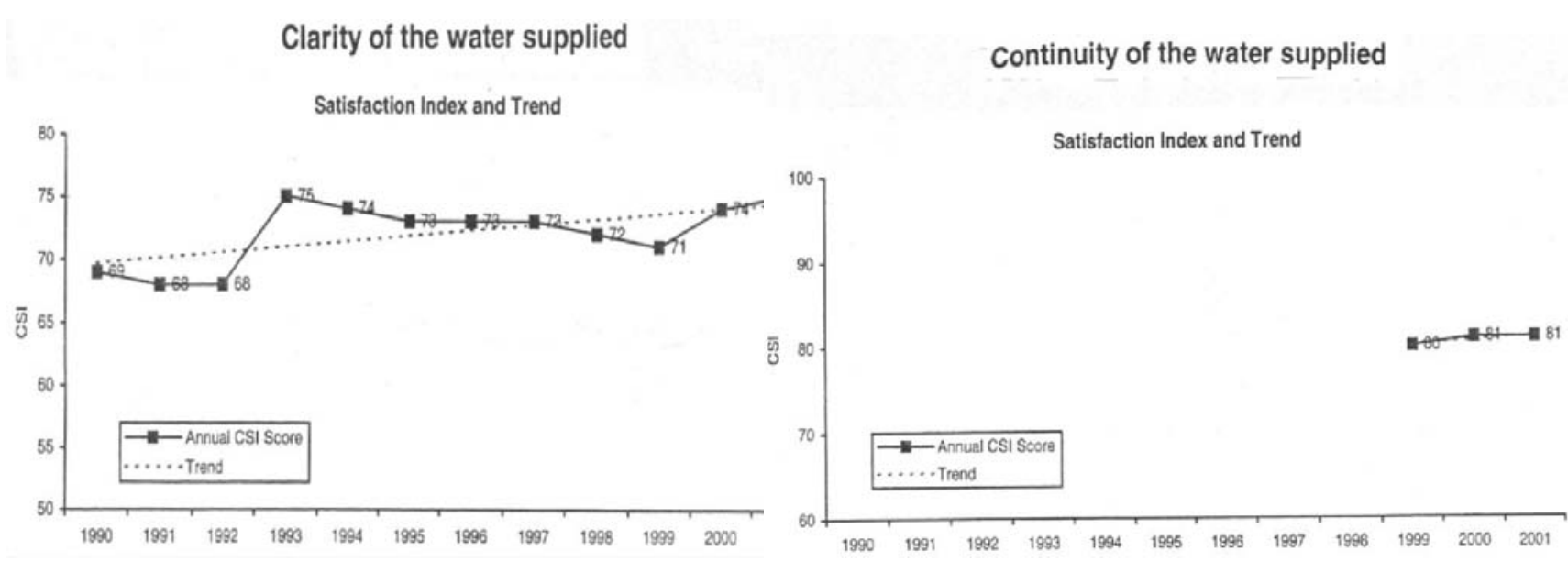

SOURCE: TLA 'A' Customer Survey, 2002 and El-Kafafi SOURCE: TLA 'A' Customer Survey, 2002 and El-Kafafi and Scrimgeour $(2002)^{[11]}$. and Scrimgeour $(2002)^{[11]}$.

Fig. 5. Water clarity satisfaction trend (1990-2001)

Fig. 6. Water continuity satisfaction trend

\section{Recommendations and conclusion}

In accordance with the TQM Model presented in Fig. 3 of this paper and the analysis of the three sets of data collection (i.e. face to face interviews, participant observations, and document review, it has been found out that the TLA under investigation has been adopting the TQM Model for over 6 years and that there has been a significant change to the organization's performance. One good indicator is their compliance to the New Zealand Drinking water Standards and maintaining an 'A' ' $a$ ' grading for the water provided to the community which is a very good score with negligible level of risk and at the same time demonstrates high quality. The TLA Water Treatment Department has been ISO 9000 certified for approximately 8 years. On the other hand, it is not ISO 14000 certified. The whole water utility is working toward applying for the New Zealand Business Excellence Award which is equivalent to the Malcolm Baldrige National Quality Award.

One of the main recommendations to this TLA is to allocate more funding for training their staff on modern technology especially that their water treatment plant is completely computerised. Last but not least, the TLA should keep up their good work and keep their innovativeness. 


\section{Taste of the water supplied}
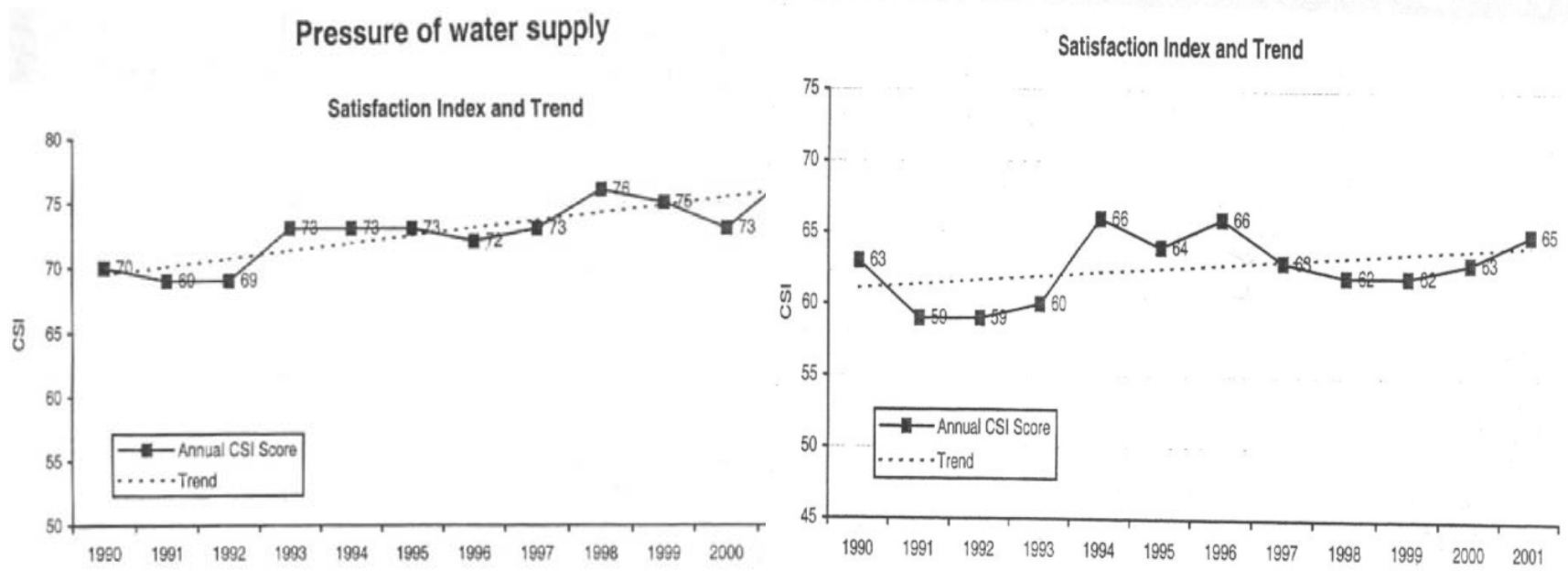

SOURCE: TLA 'A' Customer Survey, 2002 and El-Kafafi SOURCE: TLA 'A' Customer Survey, 2002 and El-Kafafi and Scrimgeour (2002) ${ }^{[11]}$. and Scrimgeour (2002) ${ }^{[11]}$.

Fig. 7. Water pressure satisfaction trend

Fig. 8. Water taste satisfaction trend

\section{References}

[1] Environment waikato strategic plan 1998-2008. Waikato Regional Council, 1994.

[2] Environment waikato strategic plan 1998-2008. Waikato Regional Council, 1998.

[3] Delivering a sustainable future: long term council community plan 2004-2014. Waikato Regional Council, New Zealand, 2004.

[4] Statistics New Zealand, Waikato District census. http: / / www . stats . govt . nz, 2005.

[5] M. Brenner. Intensive interviewing. in: The research interview: Uses and approaches, Academic Press, London, 1985, 147-162.

[6] Chapman, Hall. The american society for logistics in c.s. tapoero. 1996.

[7] I. Chien. Appendix: An introduction to sampling. in: Selltiz, Wrightsman and Cook's Research Methods in Social Relations (L. H. Kider, ed.), 4th edn., New York, 1981.

[8] F. C. Dane. Research methods. California, 1990.

[9] N. K. Denzin. The research act: A theoretical introduction to sociological methods. 2nd edn., McGraw-Hill, New York, 1978.

[10] S. El-Kafafi. Total Quality Management and drinking water quality: The Waikato Experience. Ph.D. Thesis, Waikato University, New Zealand, 2004.

[11] S. El-Kafafi, F. Scrimgeour. ISO 9000 theory and practice: Documenting a quality system in a water facility in the Waikato region of New Zealand. in: Proceedings of the 7th International Conference on ISO 9000 and TQM (7th ICIT), Melbourne, 2002.

[12] D. V. Fetterman. Applied social research methods series. in: Ethnography, vol. 17, 2nd edn., London, 1998.

[13] P. Klaus. Die qualitat von bedienungsinterakionen. in: Dienstungsqualotat: Konzepte Methoden Erfahrungen (M. Bruhn, B. Strauss, eds.), 1991.

[14] T. R. Lindlof. Qualitative Communication Research Methods, An Advanced Text, vol. 3. Sage Publications London, 1995.

[15] T. May. Social research: Issues, methods and process, 2nd edn. Open University Press, Philadelphia, 1997.

[16] S. B. Merriam. Qualitative Research and Case Study Applications in Education. Jossey-Bass Publishers, 1998.

[17] M. Patton. Qualitative Evaluation and Research Methods. Newbury Park, 1990.

[18] M. W. Riley. Social research: A case approach. 1963, 1.

[19] C. Selltiz, M. Jahoda, et al. Research Methods in Social Relations. New York, 1959.

[20] C. S. Tapiero. The Management of Quality and its Control. New York, 1996. 